\title{
BCR/ABL1 Fusion Protein
}

National Cancer Institute

\section{Source}

National Cancer Institute. BCR/ABL1 Fusion Protein. NCI Thesaurus. Code C16325.

A fusion protein encoded by the BCR/ABL1 fusion gene. This protein is comprised of the $\mathrm{N}$-terminus of the breakpoint cluster region protein fused to almost the entire tyrosineprotein kinase ABL1 protein. 